\title{
Topical Collection: 40th Anniversary of the International Marcé Society for Perinatal Mental Health: Innovations in Research, Policy and Clinical Care
}

\author{
Special Guest Editor: Lisa S. Segre
}

Published online: 1 October 2021

(C) Springer-Verlag GmbH Austria, part of Springer Nature 2021

Publisher's Note Springer Nature remains neutral with regard to jurisdictional claims in published maps and institutional affiliations. 